\title{
Placental Growth Hormone Levels in Normal Pregnancy and in Pregnancies with Intrauterine Growth Retardation
}

\author{
VÉRONIQUE MIRLESSE, FRANCIS FRANKENNE, ELIANE ALSAT, MICHELINE PONCELET, \\ GEORGES HENNEN. AND DANIĖLE EVAIN-BRION \\ Service de Médecine et Biologie Foetale /V.M.J. Institut de Puériculture, Paris, France, and Endocrinologie \\ Expérimentale et Clinique [F.F., M.P., G.H.J. Centre Hospitalier Universitaire, Liege, Belgium. \\ and Laboratoire de Physiopathologie du Développement /E.A.. D.E.-B.J. Ecole Normale Supérieure. \\ Paris, France
}

\begin{abstract}
To assess the possible role of placental growth hormone (GH) in fetoplacental growth, we measured placental and pituitary GH (GHN) in maternal plasma by means of two RIA using two MAb (5B4 recognizing both placental $G H$ and GHN, and $K 24$ recognizing only GHN) during pregnancy. IGF-I also was measured by RIA in the same samples after extraction. A transverse study of 186 samples obtained between 8 wk of amenorrhea (WA) and term confirmed the reported rise in GH immunoreactivity with $5 B 4$ after 24 to 25 WA from $12.3 \pm 2.0$ $\mathrm{mU} / \mathrm{L}$ (mean $\pm \mathrm{SEM}$ ) to a plateau of $27.5 \pm 3.4 \mathrm{mU} / \mathrm{L}$ at 34 to 35 WA together with the decrease in GHN to undetectable levels by 24 to 25 WA. IGF-I levels increased from $164.0 \pm 44.6 \mu \mathrm{g} / \mathrm{L}$ at 24 to $25 \mathrm{WA}$ to $331.6 \pm 63.6$ $\mu \mathrm{g} / \mathrm{L}$ at term. A longitudinal study of 31 normal pregnant women confirmed this hormonal pattern and the reported placental GH plateau after 35 WA. A drastic decrease in placental GH was observed with the onset of labor (from $26.9 \pm 2.1$ to $2.7 \pm 1.1 \mathrm{mU} / \mathrm{L}$ ), whereas the decrease in IGF-I was not significant (from 212.9 \pm 26.5 to $162.4 \pm$ $16.9 \mu \mathrm{g} / \mathrm{L}$ ). Interestingly, maternal plasma samples obtained after 31 WA until the initiation of labor in 22 cases of intrauterine growth retardation (six cases of toxemia, one chromosomal aberration, one maternofetal infection, 14 idiopathic) contained significantly lower amounts of placental GH $(14.9 \pm 1.6 \mathrm{mU} / \mathrm{L}$ versus $26.5 \pm 1.2 \mathrm{mU} / \mathrm{L}$ in normal pregnancies; $p<0.001)$. Plasma IGF-I levels were also lower than normal $(156.0 \pm 25.5 \mu \mathrm{g} / \mathrm{L}$ versus $285.1 \pm 40.8 \mu \mathrm{g} / \mathrm{L} ; p<0.001)$. These results suggest a relationship between placental GH levels in the maternal plasma and the development of the fetoplacental unit. (Pediatr Res 34: 439-442, 1993)
\end{abstract}

\section{Abbreviations}

GH, growth hormone

GHN, pituitary growth hormone

IUGR, intrauterine growth retardation

WA, weeks of amenorrhea

The placenta and the fetus form a functional unit during pregnancy. The correlation between placental size in late gesta-

Received December 10, 1992; accepted May 11, 1993.

Correspondence and reprint requests: Danièle Evain-Brion, Laboratoire de Physiopathologie du Développement, CNRS URA1337, 46 rue d' Ulm, 75230 Paris Cedex 05. France. tion and fetal growth is well established (1), but the placentalfetal relationship is highly complex. The human placenta recently has been shown to express the GH-V gene specifically, leading to the production of placental GH (2-4).

Placental GH differs from GHN by 13 amino acid residues, is more basic than GHN, and contains a unique N-linked glycosylation site at asparagine $140(5-7)$. Placental GH is produced by the syncytiotrophoblast in vivo $(8,9)$ and in vitro $(10)$, and we recently have demonstrated that this hormone is involved in autocrine mechanism in the syncytiotrophoblast (11).

Placental GH binds to a GH-binding protein (12) and can be biologically active mainly as a somatogen but also as a lactogen (13). Placental GH can be detected in the maternal blood and is distinguishable from GHN on the basis of its reactivity with two MAb (14). However, the precise function of placental $\mathrm{GH}$ is unknown.

IUGR for gestational age is a major clinical concern: An exponential relationship exists between the degree of growth retardation and perinatal morbidity and mortality. However, the endocrine factors accounting for this abnormal growth are poorly understood.

To assess the possible role of placental $\mathrm{GH}$ in fetoplacental growth, placental GH was measured in transverse and longitudinal studies during the course of normal pregnancies, together with maternal IGF-I. The levels were compared with those observed during fetal growth retardation of various origin diagnosed during the 3rd trimester of pregnancy.

\section{MATERIALS AND METHODS}

Subjects. Transverse study. Plasma samples were collected from healthy pregnant women from 8 WA to full term $(n=186)$ who were referred to the maternity unit of the Hopital SaintVincent de Paul (Paris). The length of pregnancy was determined as: $n$ wk of gestation $=n-2$ WA. All these women gave birth to healthy infants with a normal birth weight (mean, $3299 \pm 449$ g) according to the Leroy-Lefort curve (15). The study was approved by the local ethics committee.

Longitudinal study. Blood samples were taken every 4 to 6 wk between 15 and 40 WA from 31 healthy pregnant women. In 12 cases, blood was obtained 2 to $4 \mathrm{~d}$ before delivery and at the onset of labor (contractions monitored on a tocometer and dilating the cervix). Blood was collected in EDTA vacutainers and immediately centrifuged; plasma was stored at $-20^{\circ} \mathrm{C}$ until assay.

IUGR group. These patients $(n=22)$ were selected on the basis of clinical findings (small uterine height) confirmed by echography ( $<3$ rd percentile on Lubchenko curves) during the 3 rd trimester of pregnancy (range, 33 to $39 \mathrm{WA}$ ). The routine 
etiologic study included morphologic echography and Doppler ultrasound studies and tests for maternal hypertension and infection. Fetal karyotyping was carried out in two cases with echographic abnormalities.

The birth weight of all these infants was below the 3 rd percentile on the Leroy-Lefort chart (15). Among them 11 had an height below the 3rd percentile and the others had an height below the 25 th percentile. The head circumference of these infants ranged from the 3 rd to the 30 th percentile on the LeroyLefort chart (15). The placental weights were correlated to the birth weights. Toxemia, defined as the association of maternal hypertension, lower-limb edema, and proteinuria, was found in six cases. Maternofetal cytomegalovirus infection was detectable in one case, and fetal malformation (trisomia 18) was found in another case. The 14 remaining cases were considered idiopathic.

Hormone assays. GH was measured as previously described (10) by means of two RIA using two MAb (5B4 and K24) raised against purified hGH. The immunochemistry of the MAb and the characteristics of the relevant RIA have been reported elsewhere (14). Briefly, the affinity constants of the binding reaction with $22-\mathrm{kD} \mathrm{hGH}$ were $5 \times 10^{9} \mathrm{M}^{-1}$ and $1.02 \times 10^{11} \mathrm{M}^{-1}$ for K24 and $5 \mathrm{~B} 4$, respectively. The detection limits of the assays were 1 $\mathrm{mU} / \mathrm{L}$ (K24 RIA) and $0.5 \mathrm{mU} / \mathrm{L}$ (5B4 RIA). MAb $5 \mathrm{~B} 4$ is directed toward an $\mathrm{N}$-terminal epitope and recognizes all known placental $\mathrm{GH}$ and $\mathrm{GHN}$ variants. MAb K24 reacts with a more internal epitope, recognizing the 22-kD GHN variant but not the placental one. Placental GH thus can be distinguished from GHN by its lack of reactivity with K24. Cross-reactivity with human chorionic somatomammotropin is $<0.005 \%$ in both systems.

IGF-I was measured after acidic extraction of the plasma by means of RIA with a specific monoclonal anti-IGF-I antibody (1 IU corresponds to $192 \mu \mathrm{g} / \mathrm{L}$ ) (16).

Data analyses. Data are expressed as mean \pm SEM. Significant differences were identified with $t$ test at a threshold of $p<0.05$.

\section{RESULTS}

As shown in Figure $1 A$, the transversal study of 186 individual samples obtained from 8 to 10 WA to full term confirmed the reported rise in GH immunoreactivity with MAb 5B4 after 24 to $25 \mathrm{WA}$ (14) from $12.3 \pm 2.0 \mathrm{mU} / \mathrm{L}$ to a plateau of $27.5 \pm 3.4$ $\mathrm{mU} / \mathrm{L}$ at 34 to $35 \mathrm{WA}$ and the corresponding decrease in $\mathrm{GH}$ immunoreactivity with $\mathrm{K} 24$ from $2.7 \pm 1.1 \mathrm{mU} / \mathrm{L}$ to below the detection limit by 24 to 25 WA. After 24 to 25 WA, GH immunoreactivity measured with the $5 \mathrm{~B} 4$ thus corresponded to mainly placental GH. IGF-I levels did not vary significantly during the first weeks of gestation but increased progressively from $164.0 \pm 44.6 \mu \mathrm{g} / \mathrm{L}$ at 24 to $25 \mathrm{WA}$ to $331.6 \pm 63.6 \mu \mathrm{g} / \mathrm{L}$ at term (Fig. $1 B$ ). There was a weak correlation between individual IGF-I values and 5B4-immunoreactive GH from 26 wk of gestation to term $(p<0.04)$. Mean values of placental $\mathrm{GH}$ and IGF-I levels at each stage of pregnancy were significantly correlated $(p<0.01)$. Figure $2 A$ and $B$ shows two representative examples among 31 of $\mathrm{GH}$ immunoreactivity with $5 \mathrm{~B} 4$ and K24 in the longitudinal study. The shaded area of the figure represents the mean $\pm S D$ of plasma GH during normal pregnancy from the cross-sectional study. These two examples were chosen to show the great variability of 5B4 immunoreactivity profile from one normal pregnant woman to another. However, when this longitudinal study in 31 women was analyzed in a transversal way, it confirmed the hormone pattern observed in the transverse study, as well as the plateau of placental GH after 34 WA (Fig. 2C).

Interestingly, there was a drastic decrease in placental $\mathrm{GH}$ at the onset of labor (from $26.9 \pm 2.1 \mathrm{mU} / \mathrm{L}$ to $2.7 \pm 1.1 \mathrm{mU} / \mathrm{L}$ ). In contrast, IGF-I levels did not vary significantly $(212.9 \pm 26.5$ to $162.4 \pm 16.9 \mu \mathrm{g} / \mathrm{L}$ ).

Given this drop in placental GH with the onset of labor, the placental GH pattern in the women with IUGR was studied
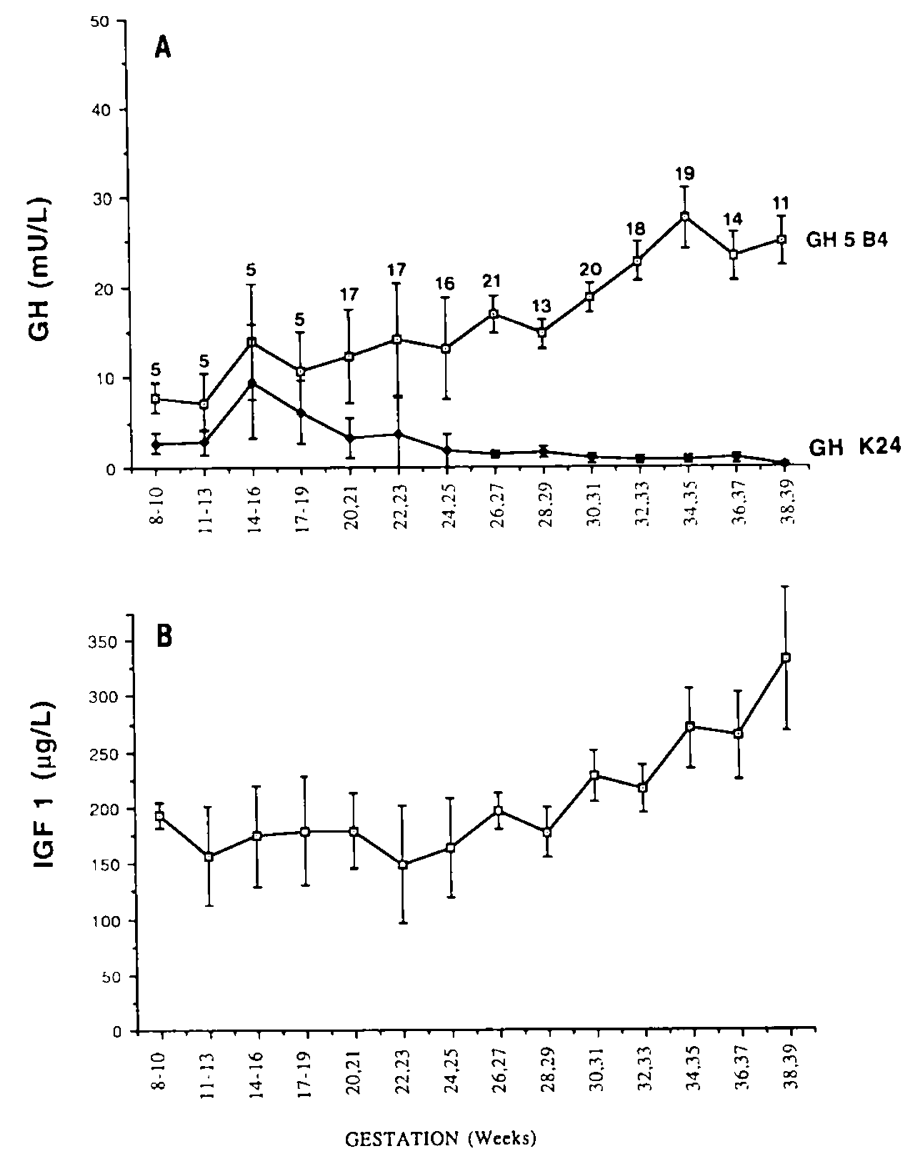

Fig. 1. Transverse study of maternal plasma GH $(A)$ and IGF-I $(B)$ levels during pregnancy $(n=186)$. Each point represents the mean \pm SEM of values from individual samples obtained in pregnant women at the indicated periods of pregnancy expressed in WA. Each period consists of $3 \mathrm{wk}$ until the 20th wk and then consists of $2 \mathrm{wk}$ thereafter. Number of individual assays in GH and IGF-I for each gestational stage is indicated in panel $A$ on top of the vertical bars.

during the 3 rd trimester of pregnancy but some time before labor. As shown in Figure 3, there was a significant decrease in placental GH (5B4 immunoreactivity) levels after 33 WA ( $p<$ $0.001)$ relative to normal pregnancies $(14.9 \pm 1.6 \mathrm{mU} / \mathrm{L}$ versus $26.5 \pm 1.2 \mathrm{mU} / \mathrm{L})$. IGF-I levels also were significantly decreased in women with IUGR (mean $\pm \mathrm{SEM} ; 156.0 \pm 25.5 \mu \mathrm{g} / \mathrm{L})$ relative to normal pregnancies $(285.1 \pm 40.8 \mu \mathrm{g} / \mathrm{L})$. According to the IUGR etiologies, there was no significant difference between placental GH and IGF-I maternal levels in IUGR associated with maternal toxemia $(n=6)$ and IUGR of unknown causes (idiopathic IUGR, $n=14$ ).

\section{DISCUSSION}

In the transverse study, we observed a progressive increase in placental $\mathrm{GH}$ levels in the maternal plasma during pregnancy, and a corresponding decrease in GHN to undetectable levels. The increase in placental GH paralleled that in IGF-I. There were large individual differences in the pattern of placental $\mathrm{GH}$ in the longitudinal study, but both GH and IGF-I were significantly reduced in the maternal plasma in the cases of IUGR.

It is well established that IGF-I levels increase gradually in pregnant women, but the factors involved are not fully understood $(17,18)$. Maternal IGF-I is mainly synthesized by the liver (19), but perfusion studies of the placenta in vitro have suggested that some placental IGF-I is secreted into the maternal circulation (20). Interestingly, maternal IGF-I levels are not under the control of pituitary $\mathrm{GH}$ during pregnancy as shown by studies of acromegalic women in whom, despite the apparent stability 

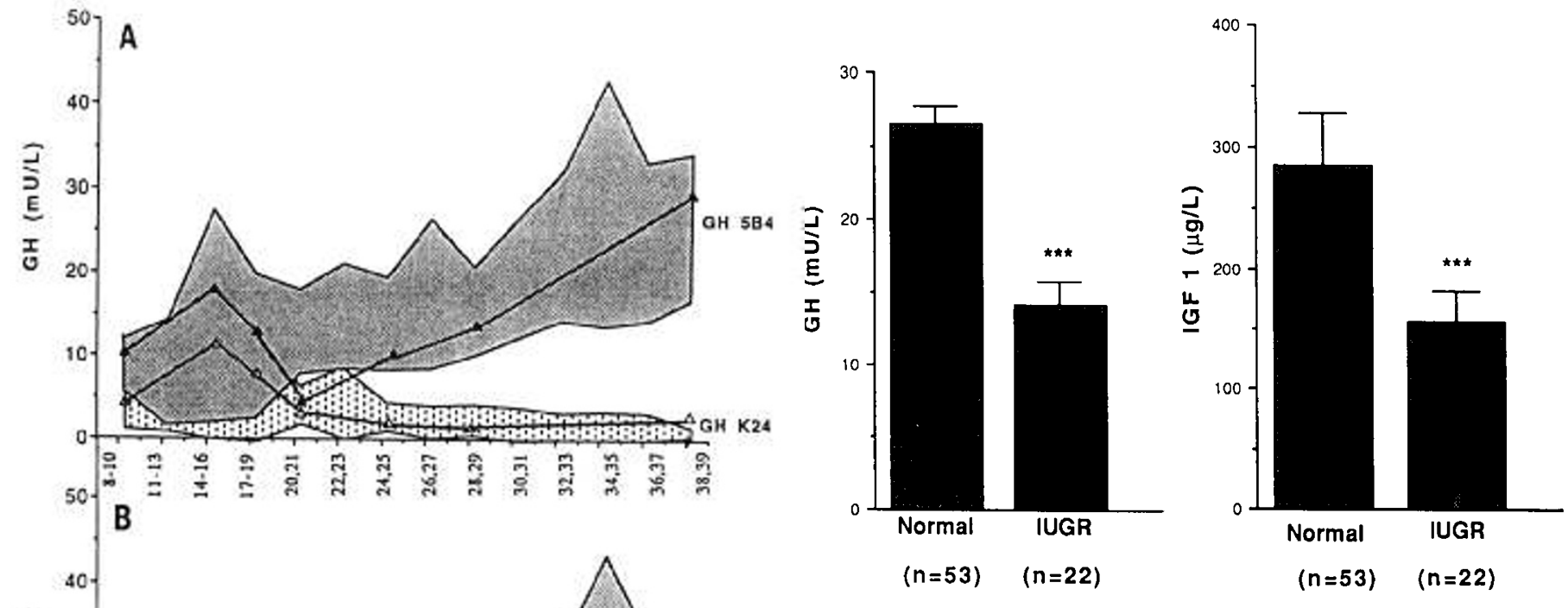

Fig. 3. Maternal plasma placental GH (5B4 immunoreactivity) and IGF-I levels in normal $(n=53)$ and IUGR $(n=22)$ pregnancies between $33 \mathrm{WA}$ and term. Vertical hars represent the mean \pm SEM. ${ }^{* * *}$. Significantly different from normal values $(p<0.001)$.

Placental GH levels fell drastically with the onset of labor. probably due to the decrease in uteroplacental blood flow $(25$, 26). In addition, a release of proteases by the placenta cannot be ruled out because placental GH has a short half-life (14). In contrast, the maternal level of IGF-I was not significantly modified by the onset of labor. This difference may be due to the longer half-life of IGF-I or to the fact that not all maternal IGFI is produced by the placenta (23). A larger study would be necessary to confirm these results and to exclude a significant decrease of IGF-I during labor, obscured in this study by the large variations of IGF-I levels in the controls.

We found a significant decrease in placental GH levels in the women with intrauterine growth retarded fetus. After 26 wk of gestation ( $28 \mathrm{WA}$ ), i.e. during the last trimester of pregnancy when most cases of IUGR are diagnosed, maternal circulating $\mathrm{GH}$ derives essentially from the placenta and is significantly reduced in cases of IUGR relative to normal pregnancies. No difference was found in the levels of placental $\mathrm{GH}$ in terms of etiology of IUGR. This suggests that placental GH levels reflect placental biologic activity and might be useful in assessing the chronic fetal distress associated with abnormal placental structure and/or function. Further studies are necessary to determine whether placental $\mathrm{GH}$ levels in the maternal plasma of pregnant women might be of value for the diagnosis and the follow-up of IUGR.

Acknowledgments. The authors thank the staff of the Department of Obstetrics and Gynecology (Hôpital Saint-Vincent de Paul, Paris) for providing the blood samples. This study was supported by grants from the European Economic Community (JU TL 91.0004), from la Fondation de Recherche en Hormonologie (No. 75.93.03), from La Fondation de France, and from la Région Wallonne.

\section{REFERENCES}

The physiologic role of placental $\mathrm{GH}$ is unknown but a direct action on fetal growth seems unlikely because placental $\mathrm{GH}$ is not detected in the fetal circulation (22). However, placental GH could indirectly modulate fetal growth either by interfering with the maternal metabolism, e.g. by increasing IGF-I levels, or by modulating placental development. Indeed, during the last trimester of pregnancy, fetal growth is normally constrained by maternal factors $(23,24)$. In addition, we recently have shown that placental $\mathrm{GH}$ is subject to autocrine control within the syncytiotrophoblast (10), which produces placental GH and expresses $\mathrm{GH}$ receptors (11).

1. Sands J, Dobbing J 1985 Continuing growth and development of the thirdtrimester human placenta. Placenta 6:13-22

2. Frankenne F. Rentier-Delrue F. Scippo ML. Martial J, Hennen G 1987 Expression of the growth hormone variant gene in human placenta. J Clin Endocrinol Metab 64:635-637

3. Cooke NE, Ray J, Watson MA, Estes PA, Kuo BA. Liebhaber SA 1988 Human growth hormone gene and the highly homologous growth hormone variant gene display different splicing patterns. J Clin Invest 82:270-275

4. Frankenne F. Scippo ML, Van Beeumen J. Igout A. Hennen G 1990 Identification of placental growth hormone as the growth hormone- $V$ gene expression product. J Clin Endocrinol Metab 7:15-18

5. Seeburg PH 1982 The human growth hormone gene family: nucleotide se- 
quences show recent divergence and predict a new polypeptide hormone. DNA 3:239-249

6. Igout A, Scippo ML, Frankenne F, Hennen G 1988 Cloning and nucleotide sequence of placental hGH-V cDNA. Arch Int Physiol Biochim 96:63-67

7. Chen EY, Liao YC, Smith DH, Barrere-Saldana HA, Gelinas RE, Seeburg PH 1989 The growth hormone locus: nucleotide sequence, biology and evolution. Genomics 4:479-497

8. Jara CS, Salud AT, Bryant-Greenwood GD, Pirens G, Hennen G, Frankenne F 1989 Immunocytochemical localization of the human growth hormone variant in the human placenta. J Clin Endocrinol Metab 69:1069-1072

9. Liebhaber SA, Urbanek M, Ray J, Tuan RS, Cooke NE 1989 Characterization and histologic localization of human growth hormone-variant in gene expression in human placenta. J Clin Invest 83:1985-1991

10. Evain-Brion D, Alsat E, Mirlesse V. Dodeur M, Scippo ML, Hennen G, Frankenne $F 1990$ Regulation of growth hormone secretion in human trophoblastic cells in culture. Horm Res (Basel) 33:256-259

11. Frankenne F, Alsat E. Scippo ML, Igout A, Hennen G, Evain-Brion D 1992 Evidences for the expression of growth hormone receptors in human placenta. Biochem Biophys Res Comm 182:481-486

12. Baumann G, Davila N, Shaw MA, Ray J, Liebhaber SA, Cooke NE 1991 Binding of human growth hormone $(\mathrm{GH})$-variant (placental $\mathrm{GH}$ ) to $\mathrm{GH}$ binding proteins in the human plasma. J Clin Endocrinol Metab 73:11751179

13. MacLeod JN, Worsley I, Ray J, Friesen HG, Liebhaber SA, Cooke NE 1991 Human growth hormone-variant is a biologically active somatogen and lactogen. Endocrinology 128:1298-1302

14. Frankenne F, Closset J. Gomez F, Scippo ML. Smal J. Hennen G 1988 The physiology of growth hormones (GHs) in pregnant women and partial characterization of the placental GH variant. J Clin Endocrinol Metab 66:1171-1180

15. Leroy $B$ and Lefort $F 1971$ A propos du poids et de la taille des nouveaux-nés à la naissance. Rev Fr Gynecol Obstet 66:391-396

16. Lassare C, Hardouin S, Daffos F, Forestier F, Frankenne F, Binoux M 1991
Serum insulin-like growth factors and insulin-like growth factor binding proteins in the human fetus. Relationships with growth in normal subjects and in subjects with intrauterine growth retardation. Pediatr Res 29:219225

17. Wilson DM, Bennett A, Adamson GD, Nagashima RJ, Liu F, De Natale ML, Hintz RL, Rosenfeld RG 1982 Somatomedins in pregnancy: a cross-sectional study of insulin-like growth factors I and II and somatomedin peptide content in normal human pregnancies. J Clin Endocrinol Metab 55:858-869

18. Caufriez A, Frankenne F. Englert Y, Golstein J, Cantraine F. Hennen G. Copinschi G 1990 Placental growth hormone as a potential regulator of maternal IGF-I during pregnancy. Am J Physiol 258:1014-1019

19. Humbel RE 1990 Insulin-like growth factors I and II. Eur J Biochem 190:445 462

20. Challier JC, Frankenne F, Bintein T, Poncelet M, Hennen G 1991 Release of placental growth hormone by perfused human placenta. Placenta 12:377378(abstr)

21. Beckers A, Stevenaert A, Foidart JM. Hennen G, Frankenne F 1990 Placental and pituitary growth hormone secretion during pregnancy in acromegalic women. J Clin Endocrinol Metab 71:725-731

22. De Zeghers F. Vanderschueren-Lodeweyckx M, Spitz B. Faijerson Y, Blomberg F. Beckers A. Hennen G. Frankenne F 1990 Perinatal growth hormone (GH) physiology: effect of $\mathrm{GH}$-releasing factor on maternal and fetal secretion of pituitary and placental GH. J Clin Endocrinol Metab 77:520-522

23. Gluckman PD 1989 Fetal growth: an endocrine perspective. Acta Paediatr Scand [Suppl] 349:21-25

24. Gluckman PD, Morel PC, Ambler GR, Breier BH, Blair HT, McCutcheon SN 1992 Elevating maternal insulin-like growth factor-I in mice and rats alters the pattern of fetal growth by removing maternal constraint. J Endocrinol $134: 1-3$

25. Janbu T, Koss KS, Nesheim BI, Wesche J 1985 Blood velocities in the human artery in humans during labor. Acta Physiol Scand 124:153-161

26. Fleisher A. Anyaegbumam AA. Schulman H, Farmakides G, Randolph $G$ 1987 Uterine and umbilical artery velocimetry during normal labor. Am J Obstet Gynecol 157:40-43 